\title{
Phosphorus Biogeochemical Cycling in a Sugar Cane Agroecosystem
}

\author{
Lopez-Hernandez, D. and D. Sequera
}

Instituto de Zoologia y Ecologia Tropical, Facultad de Ciencias,

Universidad Central de Venezuela, Caracas, Venezuela

Received 2012-06-15, Revised 2012-06-25; Accepted 2012-06-25

\begin{abstract}
The annual harvest of sugarcane plantations together with the burning of the crop before harvest, a common practice of management of sugarcane plantations in South America, leads to the loss of significant amounts of nutrients in those agroecosystems. Thus prescribed burning operations could progressively diminish the level of soil organic matter and increase nutrient deficiency in soils of sugar cane agrosystems. This study is an attempt to quantify the $\mathrm{P}$ distribution during the period of growth in a plantation of sugar cane (Saccharum officinarum) located near San Felipe, Yaracuy State, Central, Venezuela focusing on processes related to the cycling of the element as affected by burning operations. The work was performed in 4.5 ha experimental plots planted with the varieties Puerto Rico (PR) 1028 and Venezuela (V) 58-4. The principal flows of phosphorus, as well the quantities of this element in the soil-plant components were measured throughout the growing cycle of the crop (third ratoon). The inputs through precipitation (wet and dry) were high, that was associated with the intense agricultural (prescribed burning) and industrial activities occurring in the area. The annual balance for both varieties was negative $\left(-17.31\right.$ and $-23.63 \mathrm{~kg} \mathrm{ha}^{-1}$ for $\mathrm{V}$ 58-4 and PR 1028, respectively). The negative budget is mainly due to the important amounts of P that are exported with the cane stems. The losses must be compensated through fertilization; nonetheless, preliminary results indicated no response to $\mathrm{P}$ dressing, suggesting that in the studied mollisols the internal processes e.g., Organic-P (Po) mineralization and P solubilization efficiently operate generating important available P levels. It was also found that the burning of the sugar cane plantation plays an important role in the recycling of phosphorus, since $25-28 \%$ of the $\mathrm{P}$ requirements of the varieties are reincorporated into the soil from the ashes coming as bulk deposition.
\end{abstract}

Keywords: Ashes, Rain Inputs, Crop Productivity, Mollisols

\section{INTRODUCTION}

During several decades the valley of the Yaracuy River in Central Venezuela has been traditionally cultivated with sugarcane crops. However, the area has experienced in the last years, a drastic reduction in the levels of production (Sequera et al., 1984), such situation has been attributed partially to the abandonment of fertilization practices due to the elimination of subsidies. Preliminary trials of fertilization (NPK) for different varieties of sugarcane cultivated in the area indicate no crop responses, in particular to the fertilization with $\mathrm{P}$. As the soils, where have been established those essays, are mollisols, with appropriate levels of available $\mathrm{P}$, the agronomic evaluation suggest that only a fertilization of maintenance, at the beginning of the transplanting, of 50 $\mathrm{kg} \mathrm{ha}^{-1}$, as superphosphate, are enough to cover for Prequirements (Lopez-Hernandez et al., 2006).

However, the annual harvest of sugarcane (around 60-100 $\mathrm{Mg} \mathrm{ha}^{-1}$ ), together with the burning of the sugarcane crops before harvest, a common practice of management of sugarcane plantations in South America, leads to the loss of significant amounts of nutrients (Nitrogen $(\mathrm{N})$, Phosphorus $(\mathrm{P})$ and Potassium $(\mathrm{K})$ ) in theagroecosystems (Vallejo-Torres and LopezHernandez 2001; Franca et al., 2012). In Venezuelan sugarcane plantations, the harvest is done manually, thus plantations require previous burning, an operation which leads directly to atmospheric emissions $\left(\mathrm{CO}_{2}, \mathrm{~N}\right.$ gases and generation of ozone) and the production of huge

Corresponding Author: Lopez-Hernandez, D., Instituto de Zoologia y Ecologia Tropical, Facultad de Ciencias,

Universidad Central de Venezuela, Caracas, Venezuela Tel: 582126051305 
amounts of ashes. Those prescribed burning, apart from the environmental deterioration (Cancado et al., 2006), could progressively diminish the level of soil organic matter and increase nutrient deficiency in soils, particularly in elements with gaseous biogeochemical cycles as $\mathrm{N}$ and $\mathrm{S}$ (Lopez-Hernandez and HernandezValencia, 2011) and/or losses and redistribution of some elements with sedimentary cycles e.g., $\mathrm{P}$ and $\mathrm{K}$ among others (Vallejo-Torres and Lopez-Hernandez, 2001; Lopez-Hernandez and Hernandez-Valencia, 2011). In the case of $\mathrm{N}$, the deposition of reactive nitrogen has increased in the last three decades in the northern hemisphere specifically in North America and Western Europe and it has been identified as an important factor related to global environmental change particularly due to impacts on biodiversity and human health (Galloway et al., 2004). Soil depletion of Nis partially compensated, apart from fertilization and biological fixation with the inputs which can arrive in precipitation; however, for nutrients with sedimentary cycles like $\mathrm{P}$, that situation is not clear. For this reason, a better knowledge on the $\mathrm{P}$ dynamics in the agroecosystem and especially about the changes in long and short term of $\mathrm{P}$ availability in relation to management practices, is essential for a more sustainable use of sugarcane agroecosystems.

Therefore, $\mathrm{P}$ losses by fire and cane harvesting operations should be renewed on the basis of: (i) fertilization, (ii) inputs in bulk deposition and redistribution of ashes and (iii) by an internal cycling of elements, via mineralization and solubilization of appropriate internal sources that are abundant, particularly in the case of mollisols (Aguilar and Heil, 1988; Lopez-Hernandez et al., 1998).

There is not much work in the agronomy literature about phosphorus budgets and cycling. This study is an attempt to quantify the $\mathrm{P}$ distribution during the period of growth (third ratoon) in a plantation of sugarcane (Saccharum officinarum) located near San Felipe, Yaracuy State, Central, Venezuela focusing on processes related to the cycling of the element as affected by burning operations. As a result, we will develop a simple balance model of net in-and output, which involves the dynamics of the $\mathrm{P}$ in the soil-plant subsystems and enable to predict fertilization requirements in the study area.

\section{MATERIALS AND METHODS}

\subsection{Study Site}

The study was located in a sugar cane farm near San Felipe, Yaracuy State, Central Venezuela $\left(10^{\circ} 29^{\prime} 44^{\prime \prime} \mathrm{N}\right.$ and $\left.68^{\circ} 31^{\prime} 44^{\prime \prime} \mathrm{W}\right)$. The experimental site corresponds to a tropical humid climate region (1400-1700 mm of precipitation) affected by marine aerosols.
Four plots of $300 \mathrm{~m}^{2}$ within an experimental area of 4.5 ha cropped with Saccharum officinarum were selected for the installations of rain, through fall and lysimeters collectors. Study period corresponds to the analysis of the third ratoon of two sugarcane varieties (Puerto Rico (PR) 1028 and Venezuela (V) 58-4). The soil is a Mollisols, Haplaquoll (fine loam, isohiperthermic, muscovite, montmorillonitic, kaolinitic) with a $\mathrm{pH}$ of 7.4 , moderate to high effective cation exchange capacity (ECEC), total and available $\mathrm{P}$ and $\mathrm{N}$ content $\left(1500 \mathrm{mg} \mathrm{kg}^{-1}\right)$. The experimental plots were treated with malathion $\left(4 \mathrm{~L} \mathrm{ha}{ }^{-1}\right)$ in order to control pests and fertilized with urea, superphosphate and potassium chloride in a dose of 500, 50 and 100 $\mathrm{kg} \mathrm{ha}^{-1}$, respectively.

\subsection{Collection of Rain, Throughfall and Lixiviation Waters}

Collection of rain, throughfall and lixiviation waters was conducted during three consecutive years; however information here presented corresponds to the third ratoon. Trough fall sensu Park and Cameron (2008) corresponds to the rain water that either falls from foliage as 'leaf-drip' or passes directly through small gaps in the canopy as 'direct through fall', whereas lixiviation means deep percolation of waters within the soil profile.

Bulk deposition for chemical analysis was weekly sampled during one year from five gauges located in the plots. Bulk depositions (i.e., wet plus dry) were collected with plastic funnels of $18.5 \mathrm{~cm}$ internal diameter (PVC Polyvinyl Chloride) attached $4.5 \mathrm{~m}$ above soil surface and above the sugar cane canopies. The funnels were permanently open to the atmosphere; therefore, precipitation thus collected corresponds to bulk deposition and comprises the wet deposition flux and the dry deposition flux of gravitory sedimentation (Rodrigo et al., 2003). The funnels were connected to $2 \mathrm{~L}$ plastic bottles (PET, Polyethylene Terephtalate), which were first acidwashed and then rinsed with demineralised water.

Through fall waters were weekly collected in PVC funnels attached $0.30 \mathrm{~m}$ above soil surface connected to PET bottle collectors. In this study, due to the usual high variability of the through fall measures, a total of 20 collectors were installed for regular sampling. Nylon meshes were placed in the funnel necks and at the end of tube and bottle connections to prevent insects or vegetal debris from falling inside the sampling collectors.

Samples of leachates were weekly collected in six zero tension lysimeters located at $60 \mathrm{~cm}$ depth. Samples were extracted with a vacuum pump and analysed for total $\mathrm{P}$ content. The volume of percolation water was estimated according to Lopez-Hernandez et al. (2006) by using daily water balances drawn up for the area during the sampling period with weather data from a 
meteorological station that was installed for this study. Potential evapotranspiration according to Benavides and Diaz (1970) was calculated following the equation:

$$
\mathrm{PET}=1.21 \times 10^{7.45 \mathrm{~T} / 234.7+\mathrm{T}} \mathrm{x}(1-0.01 \mathrm{RH})+0.21 \mathrm{~T}-2.30
$$

where, PET is potential evapotranspiration in $\mathrm{mm} \mathrm{day}^{-1}$; $\mathrm{T}$ is mean daily temperature in ${ }^{\circ} \mathrm{C}$ and $\mathrm{RH}$ is mean relative humidity at $8: 00$ and 14.00 , the real evapotranspiration was calculated using the method of Thornthwaite and Mather (1957) that use the field capacity value and the amount of percolated water was estimated using the method proposed by Sanchez Sanchez and Quintero (1981).

More details of the collectors for precipitation, through fall and leaching waters are presented in (Lopez-Hernandez et al., 2006). During the study period, the total precipitation measured was $1752 \mathrm{~mm}$, whereas the water volume estimated from the through fall was $1124 \mathrm{~mm}$, which corresponds to 64 per cent of the total precipitation.

\subsection{Soil Sampling}

In order to study the changes in the different Pforms along the experimental period, forty soil samples $(30 \mathrm{~cm}$ depth) were randomly collected in the experimental plots. Sampling dates correspond to: at the beginning of the experimental period before transplanting and fertilization and during the third ratoon before and after burning operations. The samples were mixed up to obtain four composite samples representative of the experimental plots.

\subsection{Sampling of Sugar Cane Biomass}

\subsubsection{Above Ground Production}

One $\mathrm{m}$ lineal of the row of sugar cane plants were cut off by triplicates from above ground surface and separated in living (photosynthetic active) leaves, stems and dead material (leaves and dry stems). The materials were directly weighted in the field and an aliquot was separated to be transferred to the laboratory. After oven dried $\left(60^{\circ} \mathrm{C}\right)$ the aboveground biomass were calculated for each fraction based on dry weight per unit of cultivated land. Then, the samples of vegetation were ground and stored for later digestion and analysis of total P.

Below ground biomass: root biomass was estimated from the root material presents in $1 \mathrm{~m}^{2}$ (3 replicas for variety) soil monoliths up to $30 \mathrm{~cm}$ in depth. This procedure was used for the first months of growth of the crop. In the remaining periods, the tiller was firstly extracted and soil samples were taking with an auger (30 $\mathrm{cm}$ depth) at $0,25,50$ and $75 \mathrm{~cm}$ distance from the center of the tiller. In any of the forms of sampling, the soil was separated from the radical material by washing with water. The roots were then placed in oven until constant weight and biomass was referred to a unit area.

\subsection{Sampling of Ashes}

In the plantation of sugar cane, is a common practice to perform a burning of the crop prior to harvest in order to facilitate this operation, the fire removes the leaves (green and dry), as well as the non commercial dry stems.

An estimate of $\mathrm{P}$ losses by fires was obtained comparing the $\mathrm{P}$ content in the vegetation before and after the fire according to Pulido (1987) and Vallejo-Torres and Lopez-Hernandez (2001), The ashes produced by fire were evaluated in 8 round aluminium trays $\left(13.5 \mathrm{~cm}^{2}\right)$ which were placed randomly over the soil surface before fire and retired immediately after burning to estimate the mass of ashes and their $\mathrm{P}$ contents, losses of ashes from the agrosystem were evaluated following Pulido (1987).

\subsection{Chemical Analysis}

\subsubsection{P Analysis of Waters}

After one day of the collection, the samples were taken to the laboratory where $\mathrm{pH}$ was measured with a glass electrode. Water samples were then filtered through 0.45 $\mu \mathrm{m}$ pore size Millipore filters and phenyl mercury acetate (1 $\mathrm{mL} \mathrm{L}^{-1}$ ) was added as preservative. Rain, through fall and lixiviation waters were analyzed individually and averaged for monthly inputs. Samples were rejected when contaminated by debris and $\mathrm{P}$ was determined with the colorimetric method of Murphy and Riley (1962). The annual inputs of elements in incident rainfall, through fall and lixiviation waters to the sugar cane plantation are taken as the product of precipitation, through fall and percolation volumes and the respective chemical concentration. The values were expressed per unit area (ha).

\section{7. $P$ Analysis of Plant Materials and Soils}

The phosphorus content in tissues of sugar cane and ashes was determined based on ternary digestion $\left(\mathrm{HNO}_{3}\right.$ $\left.+\mathrm{HClO}_{4}+\mathrm{H}_{2} \mathrm{SO}_{4}\right)$ at $200^{\circ} \mathrm{C}$, until clearance. All samples of vegetation were determined by the method of Murphy and Riley (1962).

After soil grounding, total Phosphorus $(\mathrm{Pt})$ and organic Phosphorus (Po) were determined by the ignition method (Page, 1982). Additionally, the available forms of Po were determined according to the fractionation method of Bowman and Cole (1978). P in extracts was determined by the method of Murphy and Riley (1962). The P contents in plant and soil materials were expressed by unit area (ha).

\subsection{Statistical Analysis}

The difference between monthly concentration of elements in precipitation and through fall waters were carried out by t-tests $(\mathrm{P}<0.05$, student t-test $)$. 


\section{RESULTS}

\subsection{Biomass Production and Distribution of $P$ in the Agroecosystem}

Figure 1 shows the biomass of sugar cane crop and their distribution in the different organs of the plant for both varieties. As it was expected, the Stems (S) represent the largest percentage of the biomass of the crop, except at the first 60 days, when it is outweighed by the biomass of Green Leaves (GL). Stems production increases rapidly in the early stages, with an increase of the Total Biomass (TB), later the growth of stems and green leaves stops, so the total biomass remains practically constant in both varieties (Fig. 1). The production of roots $(\mathrm{R})$ was the lowest of all compartments of vegetation, although a certain underestimation can occur due to the methodology used to evaluate root production. The dead material (DM) increases throughout the development of the crop coming to exceed the amounts of green material in both varieties. The PR-1028 variety produced a higher biomass than the variety V-58 (Fig. 1).

\subsection{Distribution of $P$ during the Growth Cycle}

Figure 2 shows the accumulation of $\mathrm{P}$ in the different plant fractions for the PR 1028 and V 58-4 varieties. The amount of $\mathrm{P}$ accumulated in the stems increases speedily and almost linearly during the first 160 days of development (Fig. 2). After this interval, it stabilizes and reaches a total accumulation of 57.0 and $48.8 \mathrm{~kg} \mathrm{ha}^{-1}$ for PR 1028 and V $58-4$, respectively. $\mathrm{P}$ accumulated in leaves also presents a significant buildup in the first 60 days with a plateau up to 180 days of growth when it begins to decrease (Fig. 2). The distribution of phosphorus accumulation for both varieties is approximately the same and follows the following order: $75 \%$ is concentrated in the stems, $11 \%$ in leaves, $11 \%$ in the dry material and $3 \%$ in the roots. Almost all the material contained in the stems is able to be harvested, therefore from the system it was estimated that are removed 43 and 38 $\mathrm{kg} \mathrm{P} \mathrm{ha}{ }^{-1}$ for the PR 1028 and V-58-4 varieties, respectively.

\subsection{Accumulation of $P$ in Soil and Distribution}

The total amount of $\mathrm{P}$ in the soil (up to $30 \mathrm{~cm}$ depth) reached $2736 \mathrm{~kg} \mathrm{ha}^{-1}$ distributed in1891 (69\%) and $845 \mathrm{~kg}$ $\mathrm{ha}^{-1}(31 \%)$ as inorganic-P $(\mathrm{Pi})$ and organic-P, respectively (Table 1); on the other hand, within the fractions of Po, the moderately labile form was the dominant fraction (Table 1a) according to the method of Bowman and Cole (1978). When the P-fractions were analyzed along the cropping period, it was found a decrease in the Po fraction with the development of the sugar cane crop, whereas after burning $\mathrm{Po}$ and Pi-forms were increased (Table 1b), that last information was corroborated with a higher value of available $P$ in the soil after burning $\left(17.2 \pm 3.7{\mu g^{-1}}^{-1}\right)$ respect the $\mathrm{P}$ value in soil before fire $\left(10.2 \pm 3.3 \mu \mathrm{gg}^{-1}\right)$.

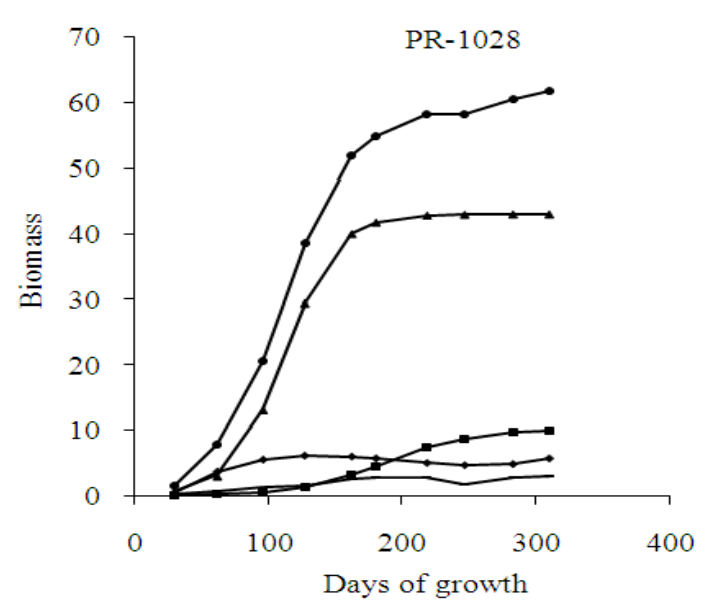

(a)

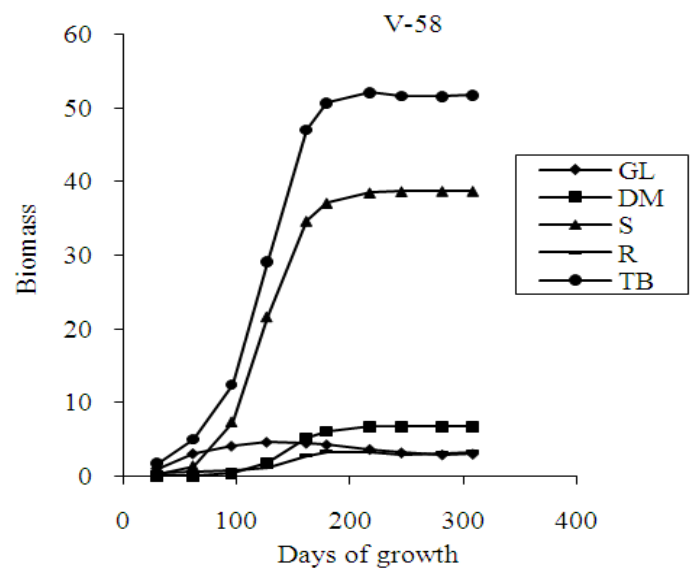

(b)

Fig. 1. Production of biomass in the different organ and tissues $\left(\mathrm{Mg} \mathrm{ha}^{-1}\right) \mathrm{GL}=$ Green Leaves $\mathrm{DM}=$ Dead Material $\mathrm{S}$ $=$ Stems $\mathrm{R}=$ Roots $\mathrm{TB}=$ Total Biomass

\subsection{Main Inputs and Outputs in the Agroecosystem}

\subsection{Phosphorus Inputs in Rain Waters and Changes on the Phosphorus Contents in the Through Fall Waters}

The monthly mean $\mathrm{P}$ concentrations in the rain water ranged from 0.10 to $1.64 \mathrm{mg} \mathrm{L}^{-1}$ (Table 2). The values exceeded the information generally presented in the literature, which are about $0.05 \mathrm{mg} \mathrm{L}^{-1}$, although there was a high variability of $\mathrm{P}$ concentrations within collectors $(n=5)$ and dates, indicating the heterogeneous influence of dry deposition, particularly the ashes deposition (Table 2). 


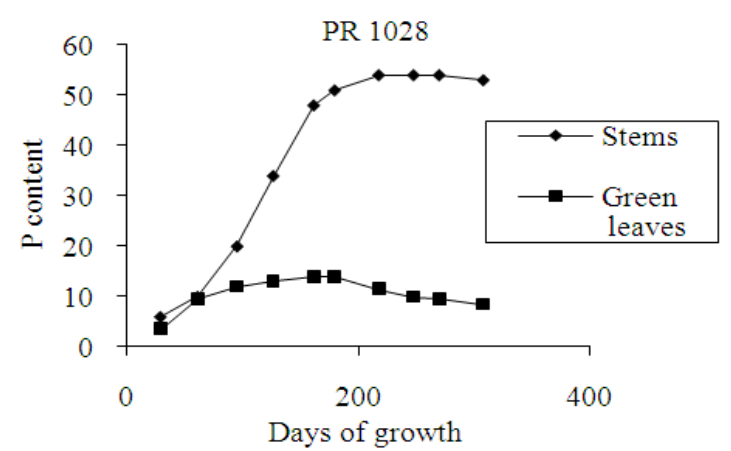

(a)

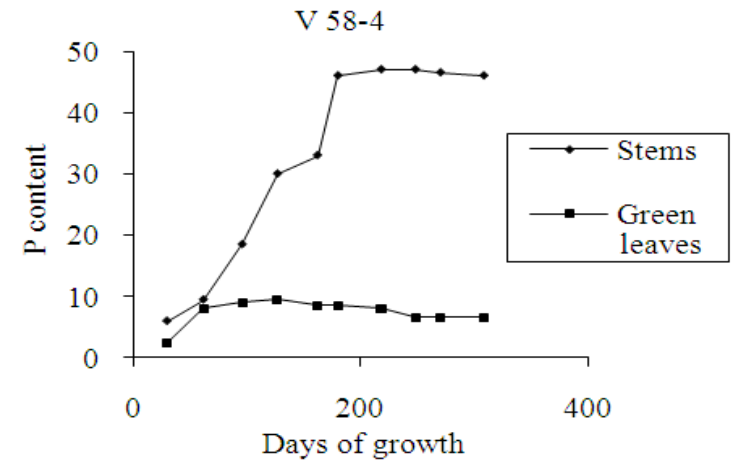

(b)

Fig. 2. $\mathrm{P}$ contents in leaves and stems $(\mathrm{kg}$ ha -1$)$

Important amounts of $\mathrm{P}$ entering the sugar cane system in the incident precipitation were retained (absorbed) in the canopy of the sugar cane agroecosystem. Therefore, a negative annual through fall of $9.87 \mathrm{~kg} \mathrm{P} \mathrm{ha}^{-1} \mathrm{yr}^{-1}$ was found (e.g., the difference between $\mathrm{P}$ input in bulk precipitation and $\mathrm{P}$ load in through fall, Table 2). The $\mathrm{P}$ entering the sugar cane system as bulk deposition (Table 2 and 3) account for a high $P$ input (14.71 kg ha ${ }^{-1} \mathrm{yr}^{-1}$ ), most of it $\left(11.01 \mathrm{~kg} \mathrm{ha}^{-1} \mathrm{yr}^{-1}\right)$ in the months when an active burning of the sugar cane plantation is taking place (November to April, Table 2); therefore dry deposition of phosphate salts might be occurring in the area. Apart from bulk deposition the sugar cane received in the experimental plots an input of $\mathrm{P}$ added as fertilizer of $11 \mathrm{~kg} \mathrm{ha}^{-1} \mathrm{yr}^{1}$ (Table 3). The ashes generated from burning and deposited on the soil floor constitute part of the internal recycling in the same form than the $\mathrm{Pi}$ coming from mineralization processes; therefore they are not considered in the final budget. In the plantation, during part of the year (at the beginning of the growing season which correspond to the transition between the dry and wet season) the sugar cane is irrigated, $\mathrm{P}$ inputs in the irrigation waters were probably insignificant when compared with the significant amount of $\mathrm{P}$ incorporated in bulk precipitation (Table 3).

Table 1a. Forms of $\mathrm{P}$ in the soil of the experimental area $\left(\mathrm{mg} \mathrm{kg}^{-1}\right)$. Values in brackets correspond to $\mathrm{kg} \mathrm{P} \mathrm{ha}^{-1}$.

\begin{tabular}{|c|c|c|c|c|c|}
\hline Inorganic P & Organic P & Total P & $\begin{array}{l}\text { Moderately } \\
\text { Labile Po }\end{array}$ & $\begin{array}{l}\text { Moderately } \\
\text { Resistant Po }\end{array}$ & $\begin{array}{l}\text { Highly } \\
\text { Resistant Po }\end{array}$ \\
\hline $573(1891)$ & $256(845)$ & $829(2736)$ & $102(334)$ & $29(96)$ & $34(112)$ \\
\hline
\end{tabular}

Table 1b. Forms of $\mathrm{P}$ in the soil of the experimental area $\left(\mathrm{mg} \mathrm{kg}^{-1}\right)$ during diverse stages of the sugar cane growing cycle (third ratoon)

\begin{tabular}{llllll}
\hline Day of growth & Inorganic P & Organic P & Total P & Moderately labile Po & Moderately resistant Po \\
\hline 30 & 467 & 277 & 744 & 250 & 27 \\
150 & 422 & 260 & 682 & 233 & 27 \\
330 & 520 & 163 & 683 & 136 & 32 \\
332 & 578 & 179 & 757 & 147 & 32 \\
\hline
\end{tabular}

Table 2. Phosphorus monthly average in bulk deposition (rain water) and leachates ( $\left.\mathrm{mg} \mathrm{L}^{-1}\right)$ in a sugarcane agroecosystem, Standard deviations in brackets. $\mathrm{P}$ inputs $\left(\mathrm{kg} \mathrm{ha}^{-1}\right)$ in rainwater and throughfall and $\mathrm{P}$ outputs $\left(\mathrm{kg} \mathrm{ha}^{-1}\right)$ in percolation waters. Net throughfall correspond to the difference between $\mathrm{P}$ input in rain water and $\mathrm{P}$ input in throughfall. * Burning operation in surrounding areas. ${ }^{* *}$ Experimental plot just burnt

\begin{tabular}{|c|c|c|c|c|c|c|}
\hline Month & Days of growth & $\mathrm{P}$ in rainwater & $\begin{array}{l}\mathrm{P} \text { input } \\
\text { rain water }\end{array}$ & $\begin{array}{l}\mathrm{P} \text { input in } \\
\text { through fall }\end{array}$ & $\begin{array}{l}\mathrm{P} \text { in } \\
\text { leachates }\end{array}$ & $\begin{array}{l}\text { P output } \\
\text { leachates }\end{array}$ \\
\hline April** & 30 & $1.40(1.17)$ & 2.41 & 0.95 & 1.36 & 0.23 \\
\hline May & 62 & $0.69(1.36)$ & 1.06 & 0.30 & $0.16(0.20)$ & 0.11 \\
\hline June & 96 & $0.41(0.69)$ & 0.14 & 0.08 & $0.09(0.07)$ & 0.00 \\
\hline July & 127 & $0.10(0.07)$ & 0.11 & 0.20 & 0.00 & 0.00 \\
\hline August & 162 & $0.41(0.33)$ & 0.94 & 0.24 & $0.31(0.52)$ & 0.33 \\
\hline September & 180 & $0.82(0.83)$ & 1.20 & 0.20 & $0.16(0.17)$ & 0.01 \\
\hline October & 218 & $0.11(0.41)$ & 0.25 & 0.15 & $0.16(0.28)$ & 0.13 \\
\hline November* & 248 & $1.28(0.93)$ & 2.76 & 0.25 & $0.28(0.29)$ & 0.20 \\
\hline \multirow[t]{2}{*}{ December* } & 270 & $1.64(0.99)$ & 5.84 & 2.47 & $0.76(0.58)$ & 2.07 \\
\hline & & & 14.71 & 4.84 & & 3.08 \\
\hline
\end{tabular}




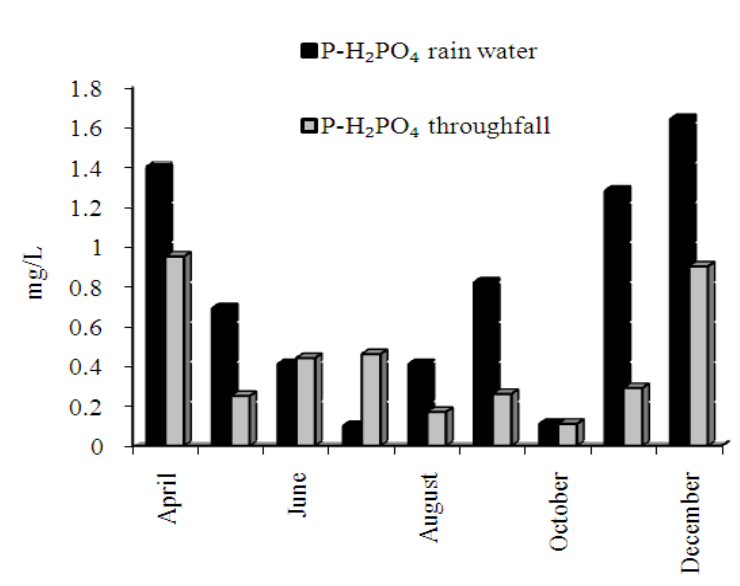

Fig. 3. Monthly weighted average concentrations of $\mathrm{P}$ (P$\mathrm{H}_{2} \mathrm{PO}_{4}$ ) in bulk deposition and through fall in a sugar cane agroecosystem

Table 3. Annual $\mathrm{P}$ budget in $\mathrm{kg} \mathrm{P} \mathrm{ha}{ }^{-1}$ for the two sugarcane varieties analyzed

\begin{tabular}{lcc}
\hline Transferences & PR-1028 & V 58-4 \\
\hline Inputs: & 14.71 & 14.71 \\
- Precipitation & 11.00 & 11.00 \\
- Fertilization & $0.00 ?$ & $0.00 ?$ \\
- Irrigation & & \\
Outputs & 3.28 & 2.28 \\
- Ashes & 3.08 & 3.08 \\
- Leaching & 42.98 & 37.66 \\
- Harvesting & -23.63 & -17.31 \\
Balance & & \\
\hline
\end{tabular}

\subsection{Main Losses: Leaching, Ashes Dispersed and Harvest}

Manually operation of harvest implies a prescribed burning of the sugar cane plantations. In Venezuela sugar cane plantation burning is operated in two opportunities, once corresponds to the burning of the dead material (stems and leaves) before harvest; the second one is done on the tufts remaining after the fire. After the burning of the plantation 2.28 and $3.28 \mathrm{~kg} \mathrm{P} \mathrm{ha}^{-1}$ $\mathrm{yr}^{-1}$ for the V58-4 and PR 1028 varieties, respectively are lost as ashes which are transported and recirculated out of the system by winds and lateral drainage (Table 3). Losses of ashes from the agrosystem by wind dispersion and mechanical transportation correspond to 42 percent of the total amount of ash material produced.

Monthly leaching losses throughout the growing season ranged from 0.01 to $0.33 \mathrm{~kg} \mathrm{ha}^{-1} \mathrm{yr}^{-1}$ (Table 2); however, the most important $\mathrm{P}$ losses by leaching from the agroecosystem occurred after burning in an unusual wet month (December) at 270 days of growth when a very high $P$ input in precipitation $\left(5.84 \mathrm{~kg} \mathrm{ha}^{-1}\right)$ and a concomitant high output in drainage waters $\left(2.07 \mathrm{~kg} \mathrm{ha}^{-1}\right)$ were recorded (Table 2).

However, the highest loss of $\mathrm{P}$ in the sugar cane agroecosystem corresponds to the cane stems which are harvested to the factory, the values corresponding to the ratoon here analyzed differ according to the variety, reaching 37.66 and $42.98 \mathrm{~kg} \mathrm{ha}^{-1} \mathrm{yr}^{-1}$ for the varieties V58-4 and PR 1028, respectively (Table 3).

\subsection{P Budgets}

The final quantification of the phosphorus budgets for the sugar cane agroecosystem indicate that each hectare planted with the variety PR1028 loses $23.63 \mathrm{~kg} P$ annually (Table 3), while that the losses for the variety V58-4 were a little lower (17.31 kg ha ${ }^{-1} \mathrm{yr}^{-1}$, Table 3). Therefore, considering that the maintenance fertilization level applied was $11 \mathrm{kgP} \mathrm{ha}^{-1}$, the agroecosystem is in a process of phosphorus impoverishment.

\section{DISCUSSION}

The biomass of the stems of the sugar cane crop increased rapidly and almost linearly during the first 160 days of growth, a similar trend presents the amount of $\mathrm{P}$ accumulated in stem's biomass (Fig. 1 and 2). At the peak of biomass production the stems present the largest percentage of the biomass of the crop and consequently they represent the main export of phosphorus within the agroecosystems, since most of the mature stems are harvested to the factory. However, a very important part of the biomass produced in the system remains within it as dead material (dead leaves and stems), green leaves and turfs which are consequently burnt before and after harvesting; in the P cycling those fluxes are recorded either as $\mathrm{P}$ coming from completely burnt ashes (dry deposition) or uncompleted (partially) burnt materials that remain in the soil floor to be later decomposed, therefore entering in the internal P cycling (Sequera et al., 1991). The curves that best fitted green biomass and stem productivity increases in sugar cane, in relation to numbers of days of growing, were sigmoidal-shaped, similar information reported Simoes et al. (2005) for total biomass and productivity in sugar cane commercial plantations in Araras, Brazil.

The $\mathrm{pH}$ of the precipitation in the studied plantation ranged from 3.54 to 4.52 (Table 4), a situation that is common in Northern Central Venezuela (where is located the sugar cane plantation) as a consequence of the high industrial (petrochemical and fertilizer production plants) and agricultural (crop fertilization and cattle raising) activities (Lewis and Weibezahn, 1981; Sequera et al., 1991; Morales et al., 1998) around the area. In the rest of Venezuela, precipitation is fairly acid (5.1-5.8) (Montes and San Jose, 1987; Lopez-Hernandez, 2008).

Concentrations of $P$ in rainfall are much affected by ash deposition, since the higher concentrations correspond to the period from November to March (Fig. 3 and Table 2), that is the period of the year when the sugar cane plantations are burnt in the areas located in the neighborhood of the experimental plot (Sequera et al., 1991). 
Table 4. Monthly average $\mathrm{pH}$ in bulk deposition, through fall and leachates in a sugarcane agroecosystem located in Central Northern, Venezuela. Bulk deposition included wet and dry deposition collected above the sugarcane canopy. Means followed by different letters differ significantly

\begin{tabular}{llll}
\hline Month & $\begin{array}{l}\mathrm{pH} \\
\text { bulk deposition }\end{array}$ & $\begin{array}{l}\mathrm{pH} \\
\text { through fall }\end{array}$ & $\begin{array}{l}\mathrm{pH} \\
\text { lixiviation water }\end{array}$ \\
\hline April & $4.52 \mathrm{~b}$ & $5.50 \mathrm{a}$ & - \\
May & $3.70 \mathrm{~b}$ & $5.26 \mathrm{a}$ & - \\
June & $3.97 \mathrm{~b}$ & $4.99 \mathrm{a}$ & - \\
July & $3.97 \mathrm{c}$ & $4.90 \mathrm{~b}$ & $6.49 \mathrm{a}$ \\
August & $4.22 \mathrm{c}$ & $5.45 \mathrm{~b}$ & $5.88 \mathrm{a}$ \\
September & $3.67 \mathrm{c}$ & $5.20 \mathrm{~b}$ & $6.15 \mathrm{a}$ \\
October & $3.54 \mathrm{c}$ & $4.50 \mathrm{~b}$ & $5.85 \mathrm{a}$ \\
November & $4.12 \mathrm{c}$ & $5.76 \mathrm{~b}$ & $6.26 \mathrm{a}$ \\
December & $4.20 \mathrm{c}$ & $5.29 \mathrm{~b}$ & $6.87 \mathrm{a}$ \\
\hline
\end{tabular}

Table 5. Phosphorus input in bulk deposition and $P$ requirements in two varieties of sugarcane in an agroecosystem located in Central Northern, Venezuela. The $\mathrm{P}$ requirements correspond to the $\mathrm{P}$ contained in biomass (stems, green leaves and roots)

\begin{tabular}{llll}
\hline $\begin{array}{l}\text { Sugarcane } \\
\begin{array}{l}\text { Variety } \\
\text { deposition }\end{array}\end{array}$ & $\begin{array}{l}\text { Precipitation } \\
\text { input }\left(\mathrm{kg} \mathrm{ha}^{-1}\right)\end{array}$ & $\begin{array}{l}\text { P requirement } \\
\left(\mathrm{kg} \mathrm{ha}^{-1}\right)\end{array}$ & $\begin{array}{l}\text { \% of P requirement } \\
\text { from bulk }\end{array}$ \\
\hline PR-1028 & 14.71 & 60.8 & 24.8 \\
V-58 & 14.71 & 53.1 & 27.7 \\
\hline
\end{tabular}

The $\mathrm{pH}$ of the bulk deposition in the sugar cane agroecosystem increased as it passed through the canopy (Table 4). Those results may reflect the significant amount of cations leached from the leaves or wash out from materials deposited on the leaves and cane stems from terrestrial dust (results to be presented elsewhere); although with the information obtained we cannot separate both effects. Moreover, a drastic increase of $\mathrm{pH}$ occurred in the percolation waters after the precipitation reached the lysimeters located at $60 \mathrm{~cm}$ depth, in this case the $\mathrm{pH}$ is controlled by the calcareous materials of the mollisols.

Leaching losses of soluble P reached $3.08 \mathrm{~kg} \mathrm{ha}^{-1} \mathrm{yr}^{1}$ (Table 3). That value is considered high according to the information of the literature for other Venezuelan environments (Montes and San Jose 1987; LopezHernandez et al., 1994) and considerable larger that have been found in natural ecosystems (Likens et al., 1977; Lopez-Hernandez and Hernandez-Valencia 2011); however this figure is particularly affected for the unusual precipitation and input of $\mathrm{P}$ occurring during the month of December (Table 2). During the months of May to October the loses reached $0.58 \mathrm{~kg} \mathrm{ha}^{-1} \mathrm{yr}^{-1}$, a value that is not surprising according to the particular characteristics of this ecosystem, a P-rich mollisols with a moderate capacity to adsorb $\mathrm{P}$ and, with dominance in the fraction of potentially mineralizable Po (Table 1). Therefore, after mineralization, Pi forms are susceptible of washing (leaching) but also could be quickly incorporated by radical absorption.
Another particular characteristic of the agrosystem under study is the presence of acid rains, the $\mathrm{pH}$ range from 3.54 to 4.52 (Table 4) associated to the intense industrial activity of the zone, consequently, the abundant Ca-P forms can easily be dissolved with the still acid throughfall that arrive at the surface of the soil (Lopez-Hernandez et al., 2012). An additional fractionation of the inorganic fraction that was performed by Lopez-Hernandez et al. (1989) showed that the $\mathrm{P}-\mathrm{Ca}$ is the main form in the inorganic reserve, which is expected, in a mollisols with significant amounts of calcium carbonate.

\subsection{P Inputs in Relationships to Sugar Cane Varieties Requirements}

Nitrogen and potassium demand in sugar cane crops are huge (Oria and Rodriguez, 1987; Thorburn et al., 2005), on the contrary the $P$ requirements of the commercial sugar cane varieties are comparatively lower (Oria and Rodriguez, 1987), although in soils with a good soil $\mathrm{P}$ status, an important amount of $\mathrm{P}$ are incorporated, as was the case of the mollisols here studied.

By using the information of the $\mathrm{P}$ accumulated in the biomass of the two sugar cane varieties analyzed (e.g., $\mathrm{P}$ contained in stems, green leaves and roots) the phosphorus requirements of the varieties were calculated (Table 5). The input as bulk deposition (14.71 kg ha $\mathrm{yr}^{-1}$ ) represents $24.8 \%$ of the $\mathrm{P}$ requirement $(60.8 \mathrm{~kg}$ $\mathrm{ha}^{-1}$ ) of PR 1028 and $27.7 \%$ of the requirement $(53.1 \mathrm{~kg}$ $\mathrm{ha}^{-1}$ ) of V58-4. The last information indicates that bulk deposition of polluted areas and ashes coming areas of active burning might be an important source of nutrient inputs to plants, which helps to cope with their nutrient needs.

\section{CONCLUSION}

By using the main input and output fluxes a negative budget was found for the sugar cane varieties studied. The negative balances registered are mainly due to the high levels of $\mathrm{P}$ that are exported via cane stems to the factory. These losses could be replaced with the application of fertilizers, however no response to fertilization with $P$ have been registered in the zone, a fact that indicates that the internal mineralization of the organic $P$ reserves together with the inputs from ashes and precipitation, as well as the possible dissolution of calcium phosphates, operate efficiently in this mollisols, generating adequate levels of available $\mathrm{P}$ to the sugar cane crop. 


\section{ACKNOWLEDGEMENT}

This study was partially funded by $\mathrm{CDCH}-\mathrm{UCV}$, CONICIT and CENAZUCA. We deeply acknowledge the useful comments of an anonymous referee.

\section{REFERENCES}

Aguilar, R. and R.D. Heil, 1988. Soil organic carbon, nitrogen and phosphorus quantities in Northern Great Plains rangeland. Soil Sci. Am. J., 52: 10761081. DOI: 10.2136/sssaj1988.03615995005200040033x

Benavides, J.G. and J.L. Diaz, 1970. Formula para el calculo de la evapotranspiracion potencial adaptada al tropico. Agronomia Tropical, 20: 335-345.

Bowman, R.A. and C.V. Cole, 1978. Transformation of organic phosphorus substrates in soils as evaluated by $\mathrm{NaHCO}_{3}$ extraction. Soil Sci., 125: 49-51.

Cancado, J.E., P.H. Saldiva, L.A. Pereira, L.B. Lara and P. Artaxo et al., 2006. The impact of sugar caneburning emissions on the respiratory system of children and the elderly. Environ. Health Perspect, 114: 725-729. DOI: 10.1289/ehp.8485

Franca, D.D.A., K.M. Longo, T.G.S. Neto., J.C. Santos and S.R. Freitas et al., 2012. Pre-harvest sugarcane burning: Determination of emission factors through laboratory measurements. Atmosphere, 3: 164-180. DOI: $10.3390 /$ atmos3010164

Galloway, J.N., F.J. Dentener, D.G. Capone, E.W. Boyer and R.W. Howarth et al., 2004. Nitrogen cycles: Past, present and future. Biogeochemistry, 70: 153226. DOI: $10.1007 / \mathrm{s} 10533-004-0370-0$

Lewis, W.M. and F.H. Weibezahn, 1981. Acid rain and major seasonal variation of hydrogen ion loading in a tropical watershed. Acta Cient. Venez, 32: 236- 238.

Likens, G.E., F.H. Bormann., R.S. Pierce., J.S. Eaton and N.M. Johnson, 1977. Biogeochemistry of a Forested Ecosystem. 1st Edn., Springer-Verlag, New York, ISBN-10: 0387902252, pp: 146.

Lopez-Hernandez D., M. Brossard and E. Frossard, 1998. PP-Isotopic exchange values in relation to Po mineralisation in soils with very low P-sorbing capacities. Soil Biol. Biochem., 30: 1663-1670. DOI: 10.1016/S0038-0717(97)00255-1

Lopez-Hernandez, D, 2008. Biogeochemistry and cycling of zinc and copper in a dyked seasonally flooded savanna. Chem. Ecol., 24: 387-399. DOI: $10.1080 / 02757540802491320$
Lopez-Hernandez, D. and I. Hernandez-Valencia, 2011. P Cycling and Biogeochemistry in Well Drained and Flooded Venezuelan Savannas. In: Horizons in Earth Science Research, Verees, B. and J. Szigethy (Eds.), Nova Science Publishers Inc., pp: 99-126.

Lopez-Hernandez, D., D. Sequera and E. Medina, 2006. Balances de elementos en un agroecosistema de caña de azucar: I. Balance de nitrogeno. Tropicultura, 24: 25-32.

Lopez-Hernandez, D., D. Sequera, O. Vallejo and C. Infante, 2012. Atmospheric Nitrogen Deposition Can Provide Supplementary Fertilization to Sugar Cane Crops in Venezuela. In: The European Nitrogen Assessment: Sources, Effects and Policy Perspectives, Sutton, M.A., C.M. Howard, J.W. Erisman, G. Billen and A. Bleeker (Eds.). Cambridge University Press, Cambridge. ISBN-10: 107006120.

Lopez-Hernandez, D., M. Espinosa and M. Niño, 1989. Transformaciones en las fracciones de fosforo organico e inorganico en un suelo calcareo fertilizado. Ciencia del Suelo, 7: 11-19.

Lopez-Hernandez, D., M. Garcia and M. Nino, 1994. Input and output of nutrients in a diked flooded savanna. J. Applied Ecol., 31: 303-312.

Montes, R. and J.J. San Jose, 1987. La Capacidad Bioproductiva de Sabanas. 1st Edn., Centro Internacional de Ecologia Tropical (UNESCO/CIET), Caracas, Venezuelapp, pp: 545.

Morales, J.A., C. Bifano and A. Escalona, 1998. Atmospheric deposition of $\mathrm{SO}_{4}-\mathrm{S}$ and $\left(\mathrm{NH}_{4}+\mathrm{NO}_{3}\right)-\mathrm{N}$ at two rural sites in the western Maracaibo Lake Basin, Venezuela. Atmospheric Environ., 32: 30513058. DOI: 10.1016/S1352-2310(97)00160-X

Murphy, J. and J. Riley, 1962. A modified single solution method for the determination of phosphate in natural waters. Anal. Chem. Acta, 27: 31-36. DOI: $10.1016 / \mathrm{S} 0003-2670(00) 88444-5$

Oria, J.R.M. and G.G. Rodriguez, 1987. La cana de azucar en Cuba. 1st Edn., Editorial CientificoTecnica, La Habana, pp: 612.

Page, A.L., 1982. Methods of Soil Analysis: Chemical and Microbiological Properties. 2nd Edn., American Society of Agronomy, Madison, Wis., ISBN-10: 0891180729, pp: 1159.

Park, A. and J.L. Cameron, 2008. The influence of canopy traits on through fall and stem flow in five tropical trees growing in a Panamanian plantation. Forest Ecol. Manage., 255: 1915-1925. DOI: 10.1016/j.foreco.2007.12.025 
Pulido, R., 1987. Mineralizacion de Nitrogeno y Perdidas de Nutrientes Por Quema en un Campo de Cana de Azucar. 1st Edn., Trabajo Especial de Grado, Escuela de Biologìa U.C.V., pp: 111.

Rodrigo, A., A. Avila and F. Roda, 2003. The chemistry of precipitation, throughfall and stemflow in two holm oak (Quercus ilex L.) forests under a contrasted pollution environment in NE Spain. Sci. Total Environ., 305: 195-205. DOI: 10.1016/S00489697(02)00470-9

Sanchez, C.J. and J.O. Quintero, 1981. Humedad del Suelo en el Campo Experimental del CENIAPMaracay. 1st Edn., X Jornadas Agronomicas, San Cristobal, pp: 918.

Sequera, D., D. Lopez-Hernandez and E. Medina, 1991. Phosphorus dynamics in a sugar-cane crop. Proceedings of the International Workshop: Phosphorus Cycles in Terrestrial and Aquatic Ecosystems, University of Saskatchewan, Saskatoon, Canada.
Sequera, P. E., D. Lopez-Hernandez and E. Medina, 1984. La produccion de Cana de Azucar en el Valle del Rio Yaracuy. 1st Edn., Fondo de Investigacion de la Cana de Azucar, Caracas, pp: 135.

Simoes, M., J.V. Rocha and R.A.C. Lamparelli, 2005. Growth indices and productivity in sugarcane. Sci. Agric., 62: 23-30. DOI: 10.1590/S010390162005000100005

Thorburn, P.J., E.A.M. Meier and M.E. Probert, 2005. Modelling nitrogen dynamics in sugarcane systems: Recent advances and applications. Field Crops Res., 92: 337-351. DOI: 10.1016/j.fcr.2005.01.016

Thornthwaite, W.C. and J.R. Mather, 1957. Instructions and tables for computing potential evapotranspiration and the water balance. Public. Climatol., 10: 183-311.

Vallejo-Torres, O. and D. Lopez-Hernandez, 2001. Micronutrient content in sugar-cane ash and its effect on a sugar-cane agroecosystem. Commun. Soil Sci. Plant Anal., 32: 409-419. DOI: 10.1081/CSS100103017 